\title{
COMPARATIVE STUDY OF BIOCHEMICAL COMPOSITION OF FIVE MICROALGAE FOR BIODIESEL/BIOPRODUCTS APPLICATION
}

\author{
R. FELLER ${ }^{1}$, A.P. MATOS ${ }^{2}$, E.H.S. MOECKE ${ }^{2,3}$, R.M. CARVALHO Jr ${ }^{4}$, R.G. LOPES ${ }^{5}$, \\ C.P.A. CAMARGO ${ }^{1}$, E.S. SANT'ANNA ${ }^{2}$, R.B. DERNER ${ }^{5}$, J.V. OLIVEIRA ${ }^{1}$, A. FURIGO \\ $\mathrm{Jr}^{1}$
}

${ }^{1}$ Federal University of Santa Catarina, Chemical and Food Engineering Department

${ }^{2}$ Federal University of Santa Catarina, Food Science and Technology Department

${ }^{3}$ South University of Santa Catarina, Environmental Engineering Laboratory

${ }^{4}$ Federal University of Santa Catarina, Atomic Spectrometry Laboratory

${ }^{5}$ Federal University of Santa Catarina, Algae Cultivation Laboratory

E-mail para contato: rafafeller@gmail.com, angelosotam@gmail.com

\begin{abstract}
The use of microalgal biomass in the production of biofuels and bioproducts are an area of research which has received attention in recent years. The aim of this study was to screen the biochemical composition of five different microalgal biomass: Chlorella vulgaris, Spirulina platensis, Scenedesmus spp., Porphyridium cruentum and Phaeodactylum tricornutum for biodiesel and bioproducts application. Green microalgae (C. vulgaris and Scenedesmus spp.) showed high protein contents $56.1 \%$ and $49.0 \%$ respectively. Red microalgae $P$. cruentum presented high carbohydrate content of about $34.5 \%$. The lipid content in microalgae biomasses ranged from 7.4 to $12.5 \%$. C. vulgaris and Scenedesmus spp. showed the highest lipid content $12.5 \%$ and $12.1 \%$, respectively. S. platensis and $P$. tricornutum showed oil rich in saturated fatty acids (SFA), specially palmitic acid (C:16:0). Monounsaturated fatty acid (MUFA) was observed at high content in P. cruentum (40.7\%). Scenedesmus spp. and C. vulgaris presented high polyunsaturated fatty acids (PUFA's), which proportions of $41.6 \%$ and $41.2 \%$, respectively. $P$. cruentum and $P$. tricornutum are also source of PUFA's, mainly eicosapentaenoic acid (EPA, 20:5) and docosahexaenoic acid (DHA, 22:6).
\end{abstract}

\section{INTRODUCTION}

Microalgae use photosynthesis to convert solar energy into chemical energy. It is stored in the form of oils, carbohydrates, proteins, etc. This energy can be converted to biofuels. In the context of climatic changes and of soaring prices for a barrel of petroleum, biofuels are now being presented as a renewable energy alternative. Presently, research is being done on microscopic algae, or microalgae, which are particularly rich in oils and whose yield per hectare is considerably higher than that of soybean or rapeseed (Richmond, 2004; Demirbas and Fatih Demirbas, 2010).

Oil productivity, that is the mass of oil produced per unit volume of the microalgal broth per day, depends on the algal growth rate and the oil content of the biomass. Microalgae 
with high oil productivities are desired for producing biodiesel. Production of biodiesel from microalgal oil can be done by transesterification reaction, that produces esters of fatty acids that are biodiesel, and glycerol (Chisti, 2007).

It is well understood that the fatty acid composition (carbon chain length and degree of unsaturation) of microalgal has a major effect on biodiesel properties. The most important characteristics affected by the level of unsaturation are oxidative stability, ignition quality and cold flow properties (Bucy et al., 2012).

The addition of microalgal biomass to food products is an interesting tool for providing nutritional supplementation with biologically active compounds (e.g. antioxidants, PUFA's), besides the high protein and carbohydrate contents. Accordingly, the selection of microalgae species with balanced nutritional profiles is fundamental for successful novel foods development. A detailed physicochemical characterization of the microalgae is an essential stage that will allow determining which algae are best suited for different applications and purposes (Batista et al., 2013).

Microalgae are present in all existing earth ecosystems, representing a big variety of species living in a wide range of environmental conditions. It is estimated that more than 50,000 species exist, but only a limited number, of around 3,000 have been studied and analyzed (Mata et al., 2010). For this purpose the screening/investigation of the biochemical composition and the fatty acids profile from microalgae strains is necessary.

\section{MICROALGAL BIOMASS}

The microalgae used in this work were cultivated in Laboratory of Food Biotechnology/Center of Agricultural Science and in Laboratory of Algae Cultivation/ Aquaculture Department, both departments located at Federal University of Santa Catarina. The growth characteristics for mass culture are shown in Table 1.

Table 1 - The main characteristics of microalgal cultures

\begin{tabular}{|c|c|c|c|c|}
\hline Microalgae & Classification & Habitat & Culture Medium & Photobioreactor \\
\hline $\begin{array}{l}\text { Chlorella } \\
\text { vulgaris }\end{array}$ & $\begin{array}{l}\text { Green algae } \\
\text { (Chlorophyta) }\end{array}$ & $\begin{array}{l}\text { Fresh } \\
\text { water }\end{array}$ & $* \mathrm{BBM}$ & $\begin{array}{l}\text { Inverted conical } \\
\text { reactor }(4 \mathrm{~L})\end{array}$ \\
\hline $\begin{array}{l}\text { Spirulina } \\
\text { Platensis }\end{array}$ & $\begin{array}{l}\text { Blue-green algae } \\
\text { (Cyanobacteria) }\end{array}$ & $\begin{array}{l}\text { Fresh } \\
\text { water }\end{array}$ & *PSM & $\begin{array}{l}\text { Inverted conical } \\
\text { reactor }(4 \mathrm{~L})\end{array}$ \\
\hline $\begin{array}{l}\text { Scenedesmus } \\
\text { spp. }\end{array}$ & $\begin{array}{l}\text { Green algae } \\
\text { (Chlorophyta) }\end{array}$ & $\begin{array}{l}\text { Fresh } \\
\text { water }\end{array}$ & *WC & $\begin{array}{l}\text { Raceway } \\
(10,000 \mathrm{~L})\end{array}$ \\
\hline $\begin{array}{l}\text { Phaeodactylum } \\
\text { tricornutum }\end{array}$ & $\begin{array}{l}\text { Brown algae } \\
\text { (Diatom) }\end{array}$ & $\begin{array}{c}\text { Sea } \\
\text { water }\end{array}$ & Guillard - f/2 & $\begin{array}{l}\text { Tank reactor } \\
(500 \mathrm{~L})\end{array}$ \\
\hline $\begin{array}{l}\text { Porphyridium } \\
\text { cruentum }\end{array}$ & $\begin{array}{c}\text { Red algae } \\
\text { (Rhodophyta) }\end{array}$ & $\begin{array}{c}\text { Sea } \\
\text { water }\end{array}$ & Guillard $-\mathrm{f}$ & $\begin{array}{l}\text { Cylinder } \\
(200 \mathrm{~L})\end{array}$ \\
\hline
\end{tabular}

*BBM, Bold Basal Medium; PSM, Paoletic Synthetic Medium; WC, Water Culture.

All the photobioreactors used in this study, recieved continuous aeration (atmospheric air). The raceway open pond and tank reactor worked using natural light. C. vulgaris, $S$. platensis and $P$. cruentum cultures were cultivated using artificial light with full photoperiod. The photobioreactors used in the microalgae cultivations were ilustrated in Figure 1. 


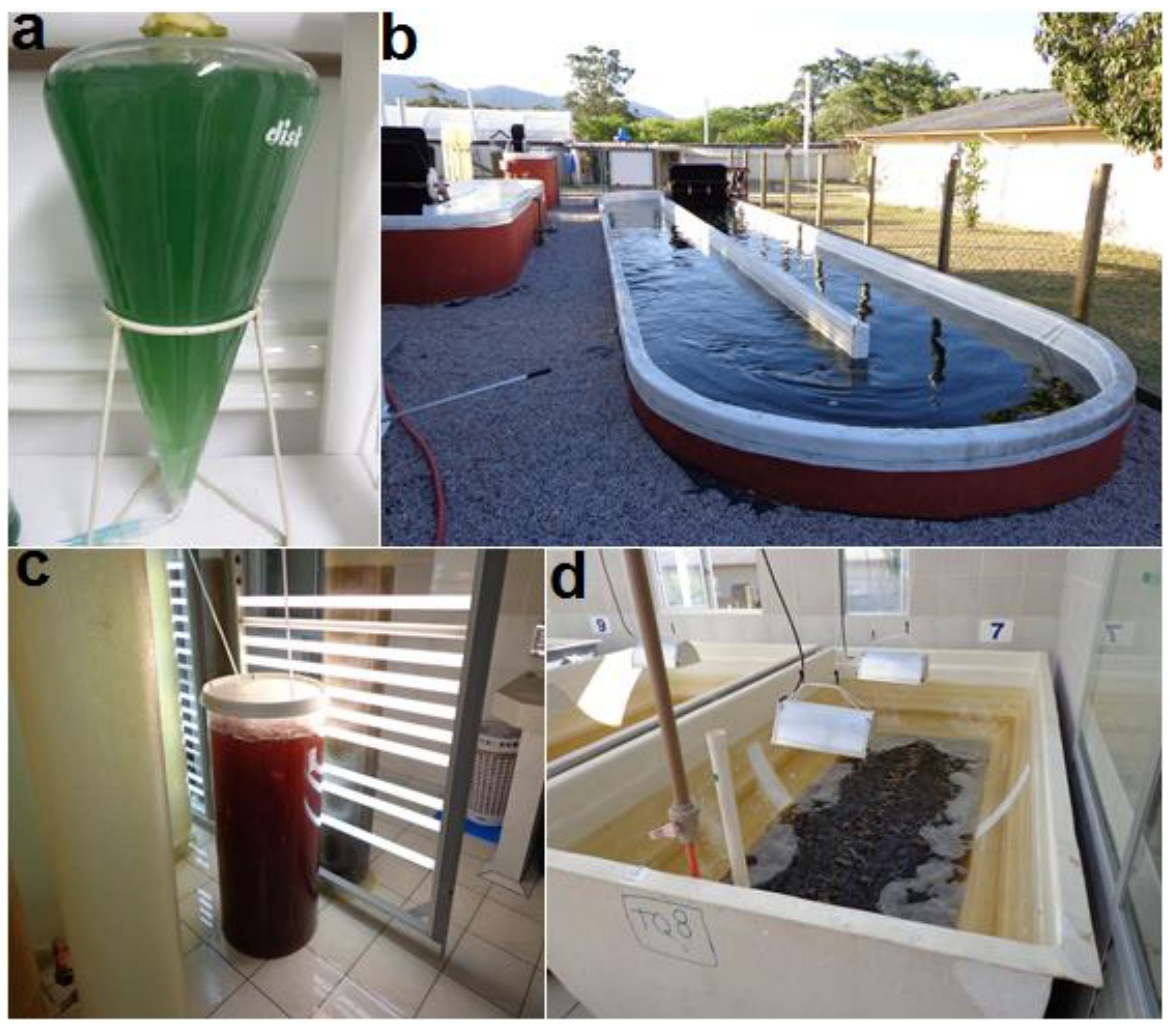

Figure 1 - Overview of algae cultivation. a. Spirulina platensis cultivated in inverted conical photobioreactor; b. Scenedesmus spp. growing in raceway open pond; c. Porphyridium cruentum cultivated in cylindrical photobioreactor; d. Tank reactor containing diatom Phaeodactylum tricornutum.

\subsection{Biomass recovery}

This step from the downstream of algae cultivation was done in Laboratory of Food Biotechnology. When the microalgae cultures reached the stationary growth phase, four liters of each culture (five different cultures) were collected and harvested by continuous centrifuging (Motortronics centrifuge, Clearwater, Florida, USA) at 4,000 rpm for approximately 1 hour. The wet paste was transferred to a dish and dried in a dehydrator at 60 ${ }^{\circ} \mathrm{C}$ (Model H-8011, Zhejiang, China). After dried, samples of microalgal biomass were sent for biochemical characterization.

\subsection{Biochemical analysis of microalgal biomass}

The biomass obtained was characterized in Laboratory of Physical Chemistry at Food Science Department. Total nitrogen was determined by Kjeldahl method after acid digestion, ammonium, distillation under steam current, and titration with $0.1 \mathrm{~N} \mathrm{HCl}$. Crude protein was calculated multiplying total nitrogen by the conventional conversion factor of 6.25 (AOAC, 2005). Total carbohydrates were determined as described by Brazil (ANVISA, 2003), following the calculated $(100 \%-($ Protein + moisture + ash + lipid + fiber $))=$ carbohydrates. Lipids were extracted by Soxhlet method with petroleum ether, during 6 hours, after acid digestion with $4 \mathrm{~N} \mathrm{HCl}$, followed by concentration in a rotary evaporator, dried in an oven 
and weighted (AOAC, 2005). The microalgae ash contents were determined by heating the samples to $550{ }^{\circ} \mathrm{C}$ for 5 hours using a carbolite muffle furnace. The moisture content was determined in the same manner but at $105{ }^{\circ} \mathrm{C}$ for 2 hours as described in the Standard Methods for the Examination of Water and Wastewater (APHA, 2005).

\subsection{Fatty acids analysis of intracellular lipids}

Fatty acids composition was determined after conversion of fatty acids to their corresponding methyl esters (AOAC, 2005). Analysis of fatty acids methyl esters (FAME) were characterized by gas chromatograph, model GC-2014 (Shimadzu, Kyoto, Japan), equipped with split-injection port, flame-ionization detector, Restek 105 m-long capillary column (ID $=0,25 \mathrm{~mm}$ ) filled with $0,25 \mu \mathrm{m}$ of $10 \%$ cyanopropylphenil and $90 \%$ biscyanopropylsiloxane. Injector and detector temperatures were both $260^{\circ} \mathrm{C}$. The oven temperature initially was set at $140{ }^{\circ} \mathrm{C}$ for $5 \mathrm{~min}$; and then, programmed at $2.5{ }^{\circ} \mathrm{C} \mathrm{min}{ }^{-1}$. Qualitative fatty acid composition was determined by comparing the retention times of the peaks with the respective standards of fatty acids (Sigma, St. Louis, USA). Quantitative composition was accomplished by area normalization and expressed as mass percent.

\section{BIOMASS CHARACTERIZATION}

The composition - proteins, carbohydrates, lipids, ashes and moisture - of five microalgae species are presented in Figure 2.

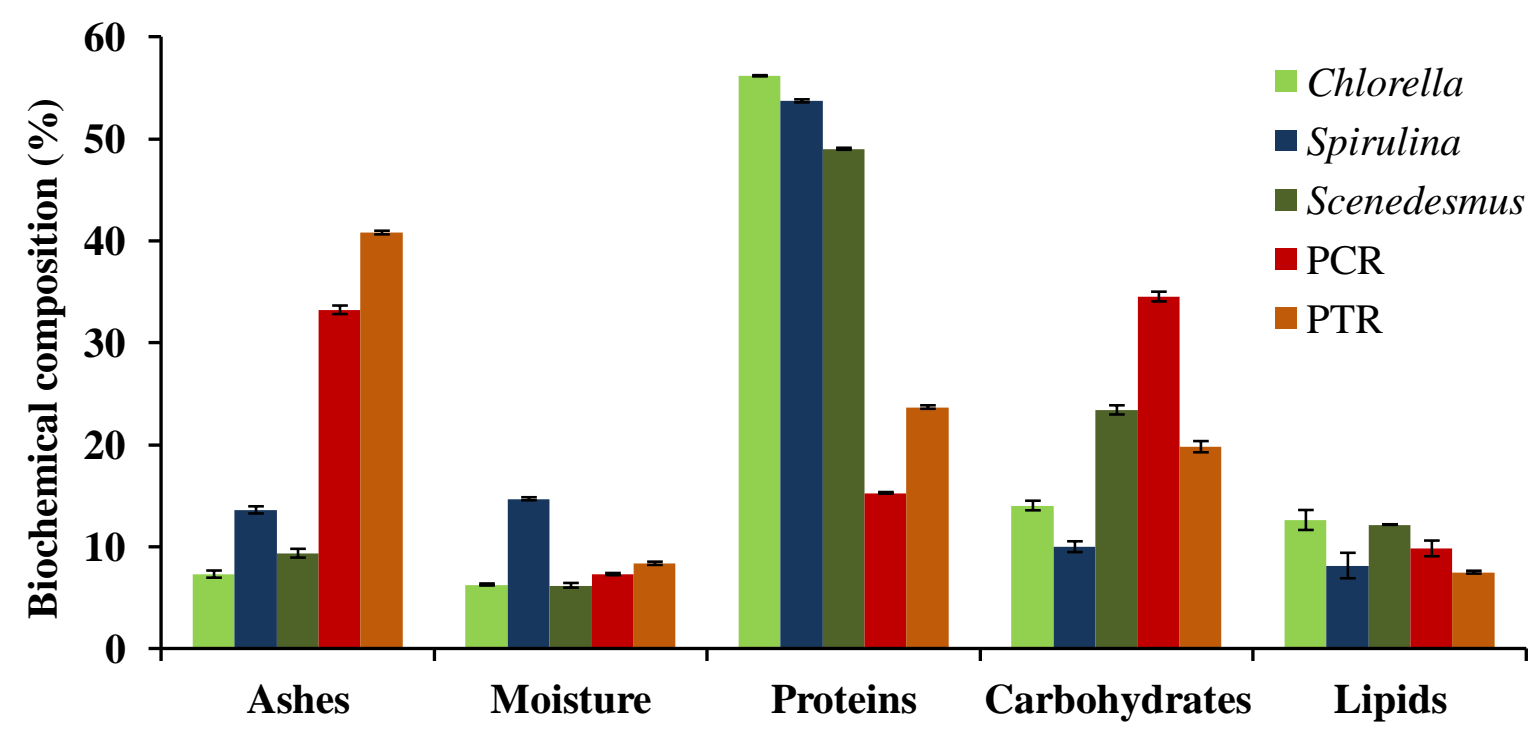

Figure 2 - Biochemical composition from five microalgae species. PCR, Porphyridium cruentum; PTR, Phaeodactylum tricornutum.

The ashes contents are more visible in the biomass of $P$. tricornutum and $P$. cruentum of about $40.7 \%$ and $33.2 \%$, respectively. This information refers to high inorganic compounds presented in the samples, especially for marine microalgae species, which is associated with high salinity presented in the culture medium. In the case of diatom P. tricornutum, its cell wall is formed by silica, which can contribute with higher salt content. For marine algae Zhu and Lee (1997) have shown that washing the wet biomass with solution of $0.5 \mathrm{M}$ of 
ammonium formate greatly reduces the salt content in dry weight of biomass. In addition, the salt content in biomass interfere the lipid extraction, and underestimates the value of other compounds.

The highest moisture content was observed in $S$. platensis, $14.6 \%$. Since that $S$. platensis biomass is widely recognized as food supplement and, for good preservation and storage, moisture should not exceed 8-9\% (Vonshak, 2002). Therefore, quick and efficient drying should be done, because high moisture content can result in the growth of yeast and bacteria in the product.

Protein is an important macro-element in living organisms including microalgae as a constituent of biomass. In this study, protein contents ranged from 15.2 to $56.1 \%$. Taking into consideration that green microalgae have high protein contents, $C$. vulgaris presented the highest protein content $(56.1 \%)$, followed by S. platensis $(53.7 \%)$ and Scenedesmus spp. $(49.0 \%)$, which were much higher than those found for marine microalgae species. It should be noted that estimations of crude protein include other nitrogen constituents, e.g., nucleic acids, amines, glucosamides, and cell wall materials, which in general is expected to account for about $10 \%$ of the total nitrogen found in microalgae (Vonshak, 2002). As seen, these microalgae have shown high protein content and can be a potential source for human nutrition (health food).

The carbohydrates in the marine microalgae studied varied between 34.5 and $19.7 \%$ for $P$. cruentum and $P$. tricornutum, respectively. Among the green microalgae studied, Scenedesmus spp. presented $23.3 \%$ carbohydrates. Carbohydrates of algae can be found in the form of starch, cellulose, and other polysaccharides, as storage products or cell wall components. While eukaryotic green algae, such as C. vulgaris and Scenedesmus spp., accumulate starch and have rigid cell walls (cellulose and hemicellulose), S. platensis uses glycogen as storage product and has thin and fragile peptidoglycan cell walls (Batista et al., 2013). For $P$. cruentum, which presented the highest carbohydrate content (34.5\%), its cell wall is mainly composed by sulfated polysaccharides, commonly made up of linear sulfated polymers and an inner rigid component, cellulose fibrils (Oh et al., 2009).

As far as the lipid content of biomass is concerned, the lipid content of biomasses varied from 7.4 to $12.5 \%$. High lipid content was observed in green microalgae (C. vulgaris, $12.5 \%$ and Scenedesmus spp., 12.1\%), while for P. tricornutum presented the lowest lipid content (7.4\%). As mentioned earlier, the lowest lipid content observed in marine species $P$. tricornutum could be seriously affected by presence of salts in dried biomass and could be underestimated the lipid content, if salts are not removed. The red algae $P$. cruentum showed lipid content (9.7\%) slightly higher than that found in S. platensis (8.1\%). Oh et al., (2009) reported for $P$. cruentum a lipid value of $19.3 \%$, which was almost 2 -fold higher than our study. In the other hand, the lipid content obtained for S. platensis $(8.1 \%)$ was 2-fold higher than that found by Batista et al. (2013) that achieved 4.0\% for Spirulina. 


\section{INTRACELLULAR FATTY ACID PROFILE}

Microalgae lipid fraction was analyzed in terms of fatty acid profile and the main fatty acids were identified (Figure 3a), as well as the proportion of total saturated (SFA), monounsaturated (MUFA) and polyunsaturated (PUFA) fatty acids (Figure 3b).
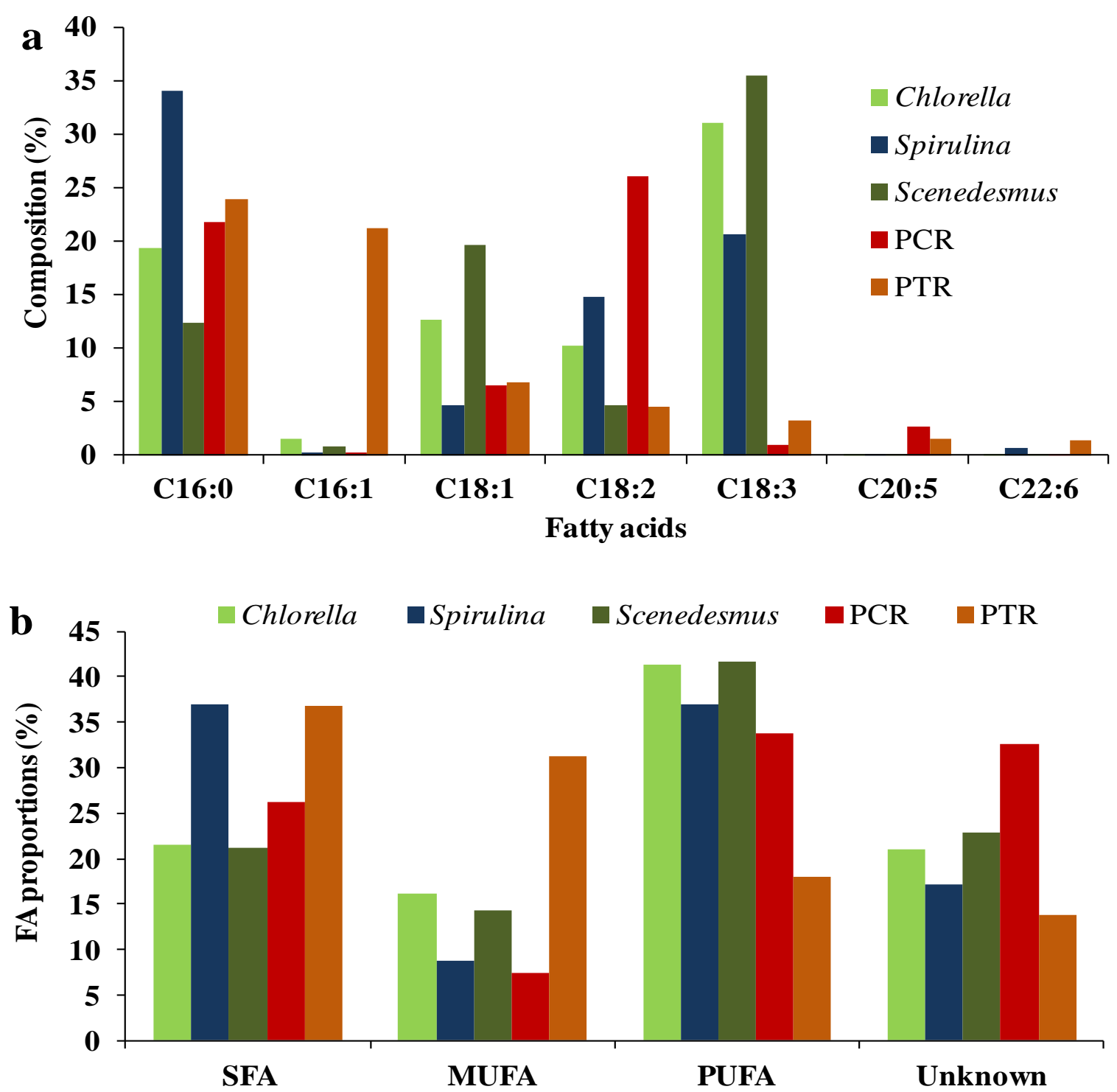

Figure $3-\mathrm{a}$. The main fatty acids composition from five microalgae species. C16:0, palmitic acid; C16:1, palmitoleic acid; C18:1, oleic acid; C18:2, linoleic acid; C18:3, linolenic acid; C20:5, eicosapentaenoic acid (EPA); C22:6, docosahexaenoic acid (DHA). b. Fatty acids proportion (FA). SFA, Saturated Fatty Acid; MUFA, Monounsaturated Fatty Acid; PUFA, Polyunsaturated fatty Acid.

S. platensis contains 37.0\% SFA, mainly palmitic acid (C16:0), and 37.0\% PUFA, with a higher proportion of linolenic acid (C18:3 $\omega 6)$. Besides linoleic acid (C18:2 $\omega 6)$, $S$. platensis is rich (20.6\%) in $\gamma$-linolenic acid (GLA 18:3 $\omega 6$ ), GLA has been associated with several beneficial health effects, such as LDL (low-density lipoproteins) reduction, precursor 
of $\mathrm{C}_{20}$ eicosanoids (prostaglandins, leukotrienes and thromboxanes), anti-inflammatory effects, reduction of pain and inflammation in rheumatoid arthritis, among others (Batista et al., 2013).

C. vulgaris and Scenedesmus spp. showed practically the same results for SFA (21.4 and $21.1 \%$ ), respectively, mainly palmitic acid (C16:0). At the same time, both algae showed similar results for PUFA at $31.0 \%$ and $35.5 \%$, respectively, mainly composed by linolenic acid (C18:3 $\omega 6)$. MUFA were obtained in high proportion in P. tricornutum (31.2\%), mainly palmitoleic acid (C16:1), which can be easy seen in Figure 2a. The most abundant fatty acid in $P$. cruentum were the linoleic (C18:2) and palmitic (C16:0) acids, which proportions were $26.1 \%$ and $21.7 \%$, respectively. Additionally, many others fatty acids from the microalgal biomass could not be identified, similar to other literature (Kaur et al., 2012).

Take into account other PUFA's (eicosapentaenoic, C20:5/EPA and docosahexaenoic, C22:6/DHA), the level of DHA are very low in S. platensis and absent in C. vulgaris and Scenedesmus spp. There is a significant level of EPA + DHA (2.8\%) in P. tricornutum and slightly higher proportion of EPA $(2.6 \%)$ in red algae P. cruentum. Considering the health benefits associated to the consumption of EPA and DHA, particularly in the prevention of cardiovascular diseases and cognitive development (Bucy et al., 2012), these marine microalgae have an enormous potential for application in health food product development.

Based on the biochemical composition results from microalgal biomass, the green microalgae cells were rich in protein which could be used for human nutrition and animal feed. The fatty acids proportion from the microalgal biomass has well-balanced ratio between the SFA/PUFA, which is an advantageous for biodiesel production. Additionally, the essential fatty acids PUFA's (EPA + DHA) from marine algal biomass are evident into the cell. PUFA's are in great demand for dietary supplements; marine algal oils could be a great source of such high-value products.

\section{CONCLUSIONS}

This study has demonstrated the potential of five microalgae strains with their biochemical composition for the purpose of biodiesel/bioproducts application. Green microalgae showed high protein contents lies at 49.0-56.1\%. Red algae P. cruentum presented the highest carbohydrate content (34.5\%) and lowest protein content (15.2\%). Lipid contents ranged from 7.4 to $12.5 \%$. C. vulgaris showed the highest lipid and protein contents of about 12.5 and $56.1 \%$, respectively. S. platensis has a well-balanced of SFA/PUFA. Palmitic acid (C16:0) was found in all types of algae studied. Green algae presented high proportion of PUFA, especially linolenic acid (C18:3 $\omega 6)$. P. tricornutum showed high proportion of MUFA, mainly palmitoleic acid (C16:1) and EPA (C20:5) + DHA (C22:6) fatty acids.

\section{ACKNOWLEDGEMENT}

The authors would like to thank CNPq and CAPES for the grants and scholarship. 


\section{REFERENCES}

American Public Health Association/American Water Works Association/Water Environmental Federation (APHA/AWWA/WEF), Standard Methods for the Examinations of Water and Wastewater, 21 st ed., 2005 Washington DC, USA.

ANVISA. Agência Nacional de Vigilância Sanitária. Resolução RDC no 360, de 23 de dezembro de 2003.

AOAC (Association of Official Agricultural Chemists International) Official Methods of analysis of AOAC International, 18 th Edition AOAC International Maryland, USA, 2005.

BATISTA, A. P.; GOUVEIA, L.; BANDARRA, M. N.; FRANCO, J. M.; RAYMUNDO, A. comparison of microalgal biomass profiles as novel functional ingredient for food products. Algal Research, v. 2, pp. 164-173, 2013.

BOROWITZKA, M. A.; MOHEIMANI, N. R. Algae for Biofuels and Energy (Developments in Applied Phycology 5). Springer (eBook), 301p., 2013.

BUCY, H, B.; BAUMGARDNER, M. E.; MARCHESE, A. J. Chemical and physical properties of algal methyl ester biodiesel containing varying levels of methyl eicosapentaenoate and methyl docosahexaenoate. Algal Research, v. 1, pp. 57-69, 2012.

CHISTI, Y. Biodiesel from microalgae: A review. Biothecnol. Adv., v. 25, pp. 294-306, 2007.

DEMIRBAS, A.; FATIH DEMIRBAS, M. Algae Energy - Algae as a New Source of Biodiesel. Londres: Springer, 2010.

KAUR, S.; SARKAR, M.; SRIVASTAVA, R. B.; GODOI, H. K.; KALITA, M. C. Fatty acid profile and molecular characterization of some freshwater microalgae from India with potential for biodiesel production. New Biotechnol. v. 29, pp. 332-344, 2012.

MATA, T. M.; MARTINS, A. A.; CAETANO, N. S. Microalgae for biodiesel production and other applications: A review. Renew. Sust. Energ. Rev., v. 14, pp. 217-232, 2010.

OH, S. H.; HAN, J. G.; KIM, Y.; HA, J. H.; KIM, S. S.; JEONG, M. H.; JEONG, H. S.; KIM, N. Y.; CHO, J. S.; YOON, W. B.; LEE, S. Y.; KANG, D. H.; LEE, H. Y. Lipid production in Porphyridium cruentum grown under different culture conditions. J. Biosc. Bioeng., v. 108, n. 5, pp. 429-434, 2009.

RICHMOND, A. Handbook of Microalgal Culture. Oxford: Editorial Blackwell Publishing Company, 2004.

VONSHAK, A. Spirulina platensis (Arthrospira): Physiology, Cell-biology and Biotechnology. Taylor \& Francis e-Library, 252p. 2002.

ZHU, C. J.; LEE, Y. K. Determination of biomass dry weight of marine microalgae. J. Appl. Phycol., v. 9, pp. 189-194, 1997. 